\section{Оценка состояния насаждений в системе озеленения г. Петрозаводска}

\author{
Ю. В. Ольхин ${ }^{1}$ \\ И. В. Морозова \\ Е. С. Ольхина \\ Петрозаводский государственный университет
}

\begin{abstract}
АННОТАЦИЯ
В статье приведены результаты оценки состояния насаждений на объектах озеленения г. Петрозаводска. Отмечены наиболее многочисленные виды деревьев и кустарников, находящиеся в неудовлетворительном санитарно-гигиеническом и декоративном состоянии.
\end{abstract}

Ключевые слова: объекты озеленения, городские зеленые насаждения, состояние деревьев и кустарников.

\section{SUMMARY}

In the article the results of an evaluation of urban stand's state on objects of gardening of Petrozavodsk are given. The most numerous species of trees and shrubs which are in unsatisfactory sanitary and decorative state are marked.

Keywords: objects of gardening, urban stands, state of trees and shrubs.

\section{ВВЕДЕНИЕ}

В настоящее время одним из актуальных вопросов экологии является оценка качества среды жизни человека [1]. Городская среда с транспортной сетью, промышленными предприятиями, большим количеством коммуникаций и сооружений, загазованностью и запыленностью воздуха, загрязнением почвы и водоемов оказывает неблагоприятное воздействие на здоровье человека.

Одним из основных средств оздоровления воздуха урбанизированных районов является развитие системы зеленых насаждений [2]. Городские насаждения должны составлять единую целостную систему озеленения для того, чтобы наилучшим образом выполнять санитарно-гигиенические функции.

Большое количество исследований было посвящено роли зеленых насаждений в улучшении санитарногигиенической обстановки в городской среде. Известно, что среди городских насаждений загазованность и запыленность воздуха значительно ниже, чем на участках без озеленения. Насаждения улучшают режим влажности и температуры воздуха, благоприятно влияют на степень подвижности воздуха, эф-

\footnotetext{
${ }^{1}$ Авторы - соответственно $\mathrm{cm}$. преподаватель $и$ преподаватель кафедры лесного хозяйства, соискатель кафедры ботаники и физиологии растений ПетрГУ

(강.В. Ольхин, И. В. Морозова, Е. С. Ольхина, 2003
}

фективно снижают уровень шума $[2,3]$. Велико значение психологического фактора - пребывание человека среди насаждений благоприятно влияет на психическое и физическое здоровье человека.

К сожалению, городская среда оказывает существенное неблагоприятное воздействие на сами растения. Растения серьезно повреждаются различными вредными выбросами. Значительно сокращается период жизни растений в городской среде. Рост рекреационных нагрузок на озелененные пространства приводит к нарушению в них экологических связей, к деградации природной среды и распаду насаждений. Рекреационные нагрузки проявляются главным образом в виде вытаптывания, наиболее подвержены воздействию которого газоны, напочвенный покров, поверхностные корневые системы.

\section{ОБЪЕКТЫ И МЕТОДЫ ИССЛЕДОВАНИЯ}

Объектами исследования служили городские насаждения в системе озеленения города Петрозаводска. В данной статье приводятся результаты оценки состояния насаждений по следующим объектам озеленения: 1) часть парка в пойме р. Лососинки от ул. Антикайнена до Комсомольского проспекта;

2) Парк культуры и отдыха;

3) парк на ул. Герцена (Парк пионеров, Губернаторский сад);

4) часть парка в пойме р. Неглинки (между ул. Антикайнена, Анохина и ул. Красной);

5) бульвар Победы на ул. Московской;

6) улица Анохина;

7) сквер на пл. Гагарина;

8) сквер на ул. Титова.

Данные для оценки состояния объектов озеленения, в том числе состояния насаждений, были собраны в 2000-2002 годах в соответствии с методами садовопарковой инвентаризации $[4,5]$. Согласно принятой методике, состояние насаждений оценивалось по трем категориям: "хорошее", "удовлетворительное" и "неудовлетворительное". Проведена оценка свыше 15000 деревьев и кустарников. На основании проведенного обмера участка составлялась схема планировки и озеленения в масштабе 1:500 или 1:1000.

\section{ОЦЕНКА СОСТОЯНИЯ НАСАЖДЕНИЙ}

Объекты озеленения отличаются не только по своим функциям, планировке, озеленению и видовому составу, но и по состоянию насаждений. На рисунке 1 представлено распределение насаждений объектов озеленения по категориям состояния.

На объекте 1 большая часть деревьев и кустарников $(70 \%)$ находится в удовлетворительном состоянии. Из древесных видов самыми многочисленными являются тополь душистый и тополь бальзамический, которые составляют $39 \%$ от общего числа древесных видов. Они же имеют самое большое число экземпляров, находящихся в неудовлетворительном состоянии ( $30 \%$ от общего числа тополей на объекте). 
Большая часть насаждений объекта 2 находится в неудовлетворительном состоянии - $53 \%$ деревьев и кустарников от общего их числа. В составе древесных растений в парке преобладают тополя, отличающиеся низкой декоративностью. Неудовлетворительную оценку получили 99\% тополей. Среди высокодекоративных видов следует отметить лиственницу сибирскую, 67\% которой имеет неудовлетворительное состояние. Этот вид часто растет в тени тополя, поэтому крона деформирована. По этой же причине аналогичную оценку состояния имеют кустарники: барбарис обыкновенный, роза морщинистая, акация желтая, спирея иволистная и спирея средняя.

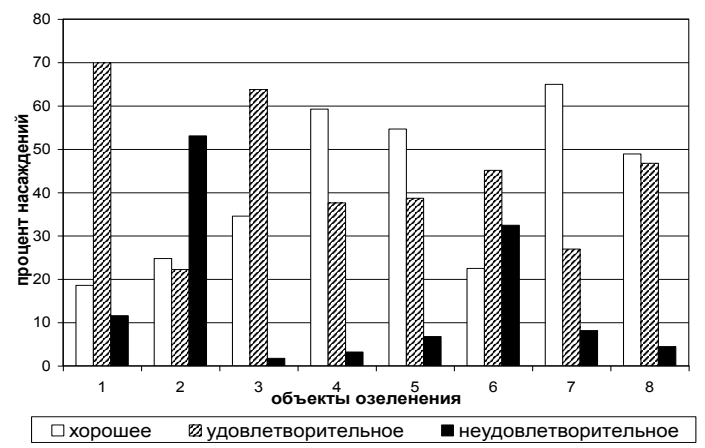

Рис. 1. Распределение насаждений объектов озеленения по категориям состояния

Объект 3 отличается довольно небольшой долей насаждений, находящихся в неудовлетворительном состоянии ( $2 \%$ деревьев и кустарников от их общего количества). В настоящее время в парке проводится преобразование существующей планировки и озеленения, что повлияет на изменение распределения категорий состояния насаждений.

Четыре объекта 4, 5, 7 и 8 характеризуются относительно высокой долей насаждений, находящихся в хорошем состоянии (рис. 1). В то же время процент насаждений с неудовлетворительной оценкой небольшой $-3,7,8$ и $4 \%$ соответственно. Виды тополя остаются самыми многочисленными среди общего количества деревьев в неудовлетворительном состоянии. Очевидно, из-за незначительного количества тополей на данных объектах процент насаждений в неудовлетворительном состоянии небольшой. В последние годы отмечается неудовлетворительное состояние ели европейской и ели колючей в сквере на пл. Гагарина и сквере на ул. Титова. Наиболее многочисленным видом, который имеет неудовлетворительную оценку состояния, является акация желтая.

Состояние насаждений на объекте 6 в целом характеризуется как удовлетворительное $(45 \%$ от общего количества деревьев и кустарников). Данный объект находится на 2-м месте после Парка культуры и отдыха по числу насаждений в неудовлетворительном состоянии (32\%). Виды тополя, так же как и на большинстве других объектов, находятся преимуще- ственно в неудовлетворительном состоянии (95\%). Неудовлетворительную оценку состояния получили рябина обыкновенная (43\%), акация желтая (56\%), спирея средняя (39\%). Из видов, у которых более $50 \%$ экземпляров находятся в хорошем состоянии, следует отметить липу мелколистную, яблоню ягодную, клен остролистный, березу бородавчатую, дуб черешчатый.

\section{ВЫВОДЫ}

1. Состояние древесных и кустарниковых насаждений обследованных объектов озеленения в целом оценивается как удовлетворительное.

2. Оценка состояния насаждений показывает, что для городских объектов озеленения требуется реконструкция планировки и объектов озеленения. В целом около 25 \% деревьев и кустарников находятся в неудовлетворительном состоянии. Такие насаждения снижают декоративность объектов озеленения, ухудшают их санитарногигиенические свойства. В реконструкции объектов озеленения необходимо использовать принципы ландшафтной архитектуры, учитывающие экологические условия и свойства растений, а также декоративные качества деревьев и кустарников.

3. В структурных насаждениях объектов озеленения экземпляры различных видов тополя, находящиеся в неудовлетворительном состоянии, нуждаются в замене более долговечными и декоративными видами.

4. Наиболее поврежденным видом в живых изгородях является акация желтая. В значительно лучшем состоянии находятся кизильник блестящий и виды спиреи. На объектах озеленения регулярного строя необходимы восстановление живых изгородей и регулярный уход за ними.

\section{СПИСОК ЛИТЕРАТУРЫ}

1. Воронков Н. А. Экология общая, социальная, прикладная. М.: Агар, 1999. 424 с.

2. Лунц Л. Б. Городское зеленое строительство. М.: Стройиздат, 1974. 275 с.

3. Машинский В. Л., Теодоронский В. С. Благоустройство и озеленение жилых районов: Рекомендации по проектированию и созданию зеленых насаждений. М., 1999. 127 с.

4. Теодоронский В. С., Кабаева И. А. Реконструкция и формирование зеленых насаждений на территории жилой застройки. М., 1999. 43 с.

5. Теодоронский В. С., Белый А. И. Садовопарковое строительство и хозяйство. М.: Стройиздат, 1989. $351 \mathrm{c.}$ 